\title{
Language barriers of the sales force in personal selling
}

\author{
Venkata Sai Srinivasa Rao Muramalla \\ College of Business Administration \\ Prince Sattam Bin Abdulaziz University, Saudi Arabia
}

Keywords

Direct selling; language barrier; personal selling; regional language; sales force; salespeople

\section{Abstract}

This paper discussed the language barriers of the sales force in personal selling. For the purpose, ten types of language barriers are tested with a sample of 180 salespeople who are chosen by convenience sampling method in two southern States of India namely Andhra Pradesh and Telangana where majority people speak in the Telugu language. By snowball sampling method, conversational interviews are conducted with the sampled sales force and investigated the specific language barrier that was highly troubled them during their conversations with the customers. From the total responses, ranks are given to each barrier. Study results revealed that in AP and Telangana more salespeople experienced the barriers of literacy, jargon, dialects, unclear sound, and accent. Few troubled by-word choice, pidgins, semantic gaps, slang, and linguistic ability. In urban markets, more salespeople averted by word choice and literacy, in rural areas more was hostile to semantic gaps and Jargon. The female sales force was more concerned with literacy, slang, and accent. More male sales representatives are apprehensive about dialects, unclear sound, and jargon. A similar study recommended by extending to other southern States in India such as Tamil Nadu, Odisha, Karnataka, and Maharashtra, to find out the barriers of Indian regional languages in direct selling at rural and urban markets.

Corresponding author: Venkata Sai Srinivasa Rao Muramalla

Email addresses for the corresponding author: s.muramalla@psau.edu.sa

First submission received: $12^{\text {th }}$ December 2017

Revised submission received: $27^{\text {th }}$ March 2018

Accepted: $18^{\text {th }}$ July 2018

\section{Introduction}

Personal selling industry across the world has grown since last two decades (Harrison \& Hair, 2017). Introduction of mobile phones and wearable technologies (Poon et al., 2017) transformed the communications (Feng, Guo, \& Chiang, 2009; Thaler \& Tucker, 2013) that resulted in transformations of consumers' behaviors (Román \& Rodríguez, 2015). Meanwhile, marketers have exploited the online and virtual interface technologies (Geiger \& Turley, 2006) to communicate and interact with customers (Swani, Brown, \& Milne, 2014).

Therefore, armed with online and offline accessible capabilities, the present generation shoppers are engaging in purchases (El Banna, Papadopoulos, Murphy, Rod, \& Rojas-Méndez, 2018) without the influences of retailers' promotion strategies (Trivedi, Gauri, \& Ma, 2017) or the strategies of sales force to convince them to make a sale (Homburg, Müller, \& Klarmann, 2011; Agnihotri, Gabler, Itani, Jaramillo, \& Krush, 2017). However, customers would favor the products (R. Singh, Kumar, \& Puri, 2017) that are often communicated them in local regional languages (MacKenzie, 2009; Dragojevic, Berglund, \& Blauvelt, 2018).

In India, because of multi-lingual profiles of customers (Mackey, 1966; Chaudhary, 2008) particularly in South-India where people use various local and regional languages (Solomonson, 1922), several companies are still muted before their customers and they are in misery to deal with their products (Madan Shankar, Kannan, \& Udhaya Kumar, 2017). Normally, differences in the local regional languages (Bhattacharya, 2017; Upadhyay \& Hasnain, 2017) does exist among Indians living in urban and rural areas (Laitin, 1993). Because, they use languages with different slang, accents, semantics, and vocabularies (Factors, Maintenance, \& Shift, 2000). Therefore, same words would convey different meanings in the conversations of Indians (Annamalai, 2008; Groff, 2017). 
Though the products in India branded and labeled in English or Hindi languages, few products are also accessible in local regional languages (Gregory \& Bhatia, 2002) and the reason is that the official language in India is English (Plough, 2014; Proctor, 2014) and majority people are speaking Hindi (J. K. Singh, Misra, \& De Raad, 2013; Shukla, 2006). Besides, consumer markets in India are well-developed (Shree, Gupta, \& Sagar, 2017) and the companies realized that the potential buyers are also in the Indian rural markets (Verma, 1980). Consequently, companies try to communicate with customers in their local regional languages across the country (D. Singh, Pattnaik, Gaur, \& Ketencioglu, 2018).

About the Telugu language in India, $7.19 \%$ speak Telugu mainly in southern States (Census of India, 2011) and it is the common regional language to more than $75 \%$ of people in the two southern States of India namely Andhra Pradesh (AP) and Telangana. In this context, this paper focused on language barriers of the sales force and deliberated their difficulties in conversations with the customers during the personal selling in two southern States of India such as AP and Telangana where majority people speak in Telugu language (Trautmann, 2004; Bhaskararao \& Ray, 2017).

\section{Personal selling in India}

Personal selling, also referred as direct selling, is the marketing of products for person-to-person (Hammann, 2005; Weitz \& Bradford, 1999) and it also referred as non-store retailing (Jones, Brown, Zoltners, \& Weitz, 2005). However, direct marketing is advertising of products and seeking the customer responses directly through various formats like emails, text messaging, and telemarketing. Whereas, personal selling or direct selling is the demonstration of products to the customers by the salespeople (Granfield \& Nicols, 1975).

Most often personal selling activities happen at the customer locations usually away from the fixed retail outlets (Albers, Raman, \& Lee, 2015). It would benefit the customers because of some trail usages of products offered to the customers during personal selling (Shannahan, Bush, Shannahan, \& Moncrief, 2017). As the oldest and more conventional method of selling activities, personal selling encourages the sales force to communicate formally with customers in local regional languages (Agnihotri, Vieira, Senra, \& Gabler, 2016).

Primarily, the modern form of personal selling in India (Sharma, 2016) is started by Eureka Forbes in 1982. Well along in years to come other global players are also arrived such as Amway, Tupperware, Avon, and Oriflame etc. Indeed, after liberalized the Indian economy in 1991, several multinational companies are adapted the direct selling methods. Since then personal selling industry has a significant growth in India and it emerged as one of the successful industries in the country.

It is estimated that personal selling industry in India will reach INR 645 billion by 2025 with a tremendous growth (Euromonitor, 2012) that will record in the consumer markets along with FMCG sector of India (KPMG, 2017). Region-wise market size of personal selling has a major share in north region of India ( $29 \%$ share, $12 \%$ growth) followed by south region ( $25 \%$ share, $13 \%$ growth), east region (18\% share, $10 \%$ growth), west region (16\% share, $11 \%$ growth), and north-east region $(12 \%$ share, $14 \%$ growth). The following sub-section briefed the size of the sales force in India.

\section{Salesforce in India}

Being the labor-intensive industry, personal selling needs both unskilled and under-skilled workforce (Reid, Plank, Peterson, \& Rich, 2017). It provides income to the sales force from sales commissions apart from wages and salaries (Kräkel \& Schöttner, 2016). However, sales commissions are earned based on sales took place because of an individual sales person's efforts (Basu, Srinivasan, \& Staelin, 1985) or it would earn by cumulative sales done by the group of sellers (Caldieraro \& Coughlan, 2009; Madhani, 2013).

According to industry reports, more than five million people in India are engaged in personal selling and the majority of them are female (58\%). In total, 0.35 million people are working in the States of AP and Telangana and 0.16 million of them are female. Hindustan Unilever Limited (HUL) is engaged only female (Larsen, 1993) for marketing of their beauty products in India and it is also started small entrepreneurial groups like 'Shakthi Ammas' as small-scale industries in South India to empower the village women by marketed their produced goods (hul.co.in, 2018). 
However, Government is implementing guidelines for direct selling activities in India and the laws are enacted to control the pushing of sales through increasing pressure on sales force and harassments of companies on sales personnel to achieve the frightening sales targets (The Tribune, 2012). This initiative is also protecting the sales force from the unauthorized products (Quach \& Thaichon, 2018) or Ponzi schemes of direct sellers (Becton, Gilstrap, \& Forsyth, 2017; Gabler \& Hill, 2015). In addition, these guidelines also envisage the minimum pay protection and the rights of the sales force for career advancements in the personal selling industry.

In order, marketers have trained their sales force (Smith, Andras, \& Rosenbloom, 2012) on salesmanship (Homburg et al., 2011) and soft skills (Hansen, Lund, \& DeCarlo, 2016) to inflate the sales in the country. For example, Amway conducted more than 20,000 training sessions in 2016 and trained nearly 0.5 million people; Oriflame organized 3,000 training sessions in 2015 and each session has nearly 100 persons. These trainings are helpful to the sales force (Krishnamoorthy, Misra, \& Prasad, 2005) to gain an in-depth knowledge of companies' products (Mariadoss, Milewicz, Lee, \& Sahaym, 2014) and to improve their interpersonal skills (Sunardi, Widyarini, \& Tjakraatmadja, 2012) as well as develop the leadership and team building skills to generate the sales (Albers, Krafft, \& Mantrala, 2010).

However, several segments of training for the sales personnel also providing unique communication skills to the sales force for dealing with the customers of business markets (Siguaw, Kimes, \& Gassenheimer, 2003). As a result, the sales force would imbibe the effective communication skills to influence the buying decision process of customers in either consumer markets or business markets. Particularly, the development of language skills of sales force during the training programs is crucial in this process. In fact, many barriers would still influence the conversations of the sales force while communicating with customers. The following section briefed on causes of language barriers that would generally trouble the sales force in personal selling.

\section{Language barriers in personal selling}

People express their feelings, ideas, thoughts, and knowledge through language (Anderson, 2012). In personal selling, language is central and it would portray the linguistic profiles of buyers and sellers (DeVincentis \& Rackham, 2015). Typically, few features of language would impede the conversations of the people (Fishman, 1989) such as semantic gaps, word choice, pidgins, slang, accents, unclear sound, linguistic ability, literacy, jargon, and dialects (Businesstopia.net, 2018). Indeed, these features handled inappropriately would become barriers to effective conversations between the people (Salzmann, 2003). Yet, their meanings are as follows:

Semantic gaps are differences in the descriptions of objects. Word choice is some sarcasm or negative meanings of used words. Pidgin is an artificial language generated by the speakers of different languages. Slang is an informal language of people to create an atmosphere of intimacy in conversations. The accent is the pronunciation of words differently and oral expressions of people in distinctive manners. The unclear sound is the small or a soft voice not clearly audible. Linguistic ability is the capability of people to use the language that is understandable to each other. Literacy is knowledge of a language that would help to read and write in that language. Jargon is a technical word used by a group of people living in the same locations. Dialects are the altered versions of the vocabulary of people living in same locations or part of a country.

Apparently, in the northern States of India, the majority of people speak in Hindi and salesforce are somehow comfortable to interact with their customers (LaDousa, 2010). On the other side, in the southern States of India salespeople would experience the language barriers (Sravanthi, Prathyusha, \& Mamidi, 2015; Murphy, 2012) for the reason that the people in these States use different local regional languages that are dissimilar (Eira, 2008). Therefore, direct sellers in south India have employed the sales force familiar to south Indian languages (Sandhu, 2015) such as Tamil, Telugu, Malayalam, Marathi, and Kannada (Sreekumar, 2009). Naturally, people use these languages with variations in slang, accents, and vocabularies (Madalli \& Patel, 2009).

\section{Problem statement}

This study is keen to know the worries of the sales force in the two southern States of India namely $\mathrm{AP}$ and Telangana where people use Telugu as core language with some differences in their language. 
Initially, the language of Sanskrit and Prakrit and its grammar has an influence on vocabulary and phonetics in the Telugu language. Subsequently, the Telugu language is considerably extended by borrowed the additional sets of jargons from English and Perso-Arabic languages. Afterward, few other languages are also emerged in the usage of Telugu by a minority in both the States of AP and Telangana (mapsofindia.com, 2013).

In AP, 80\% speaks Telugu, 10\% speaks Hindi, and 10\% speaks other languages such as English, Urdu, Tamil, Kannada, Marathi, Oriya, and Banjara. In Telangana, 77\% speaks Telugu, 12\% speaks Urdu, and 13\% speaks other languages maybe Hindi, English, Kannada, Marathi, Lambadi, and Gondi. Generally, people in Telangana mix Telugu and Urdu as such the Nizams of Hyderabad ruled this region and they had Urdu as their official language until 1948.

Moreover, people of both States have contemporary influences from the languages of their neighboring States that use Bengali, Kannada, Marathi, Malayalam, Oriya, and Tamil. Arbitrarily, this sort of multi-linguistic credentials of people in both the States would impede the conversations (Glaz, 2001) that would imply to the one-to-one conversations between the sales force and customers in personal selling.

In this context, this study felt that identifying the specific features of language that would become barriers to salespeople in both AP and the Telangana States in India would make some logic to understand the problems of salespeople in India who use the local regional languages in personal selling.

\section{Methodology}

The aim of this study is to discuss the language barriers that would highly trouble the sales force in personal selling. By using the convenience-sampling method, 180 salespeople in the States of AP and Telangana in India are chosen as the sample of this study. The details of the sample are provided in the sub-section 3.1.

By the snowball-sampling method, conversational interviews are conducted with the sampled sales force (Currivan, 2011) who speak with customers only in the Telugu language. Through these interviews, I allowed clarifying the questions of sampled sales force regarding the language barriers by providing the unscripted meanings of each barrier if they are not understood the question. This helped me to record the personal experiences of the participants about the language barriers during their interactions with customers (Lavrakas \& Battaglia, 2008). Mainly, the ten features of the language are openly explained to the salespeople such as semantic gaps, word choice, pidgins, slang, accent, unclear sound, linguistic ability, literacy, jargon, and dialects. Then it is requested the participants to point out a specific feature that was highly troubled them during their interactions with the customers.

Finally, by standard competition ranking method (spoj.com, 2018), ranks are allotted to each feature of language based on the number of participants highly troubled in that feature. The overall study results are appended to this paper.

\section{Sample}

The participants of this study are both male and female sales force in urban and rural markets of the two selected States in India. Details of the sample are showed below.

\begin{tabular}{lllllllllll}
\hline State & total & $\%$ & male & $\%$ & female & $\%$ & urban & $\%$ & rural & $\%$ \\
\hline AP & 94 & 52.0 & 54 & 54.0 & 40 & 50.0 & 50 & 57.5 & 44 & 47.0 \\
Telangana & 86 & 48.0 & 46 & 46.0 & 40 & 50.0 & 37 & 42.5 & 49 & 53.0 \\
\hline Total & 180 & 100.0 & 100 & 100.0 & 80 & 100.0 & 87 & 100.0 & 93 & 100.0 \\
\hline
\end{tabular}

\section{Findings}

Table 1 exhibited the ranks of language barriers which are extracted from the overall study results appended to this paper. Firstly, by observing the inclusive study results as shown in the appendix; it came to know that the sales force in both AP and the Telangana States really perceived the barriers in the Telugu language. However, the study findings are as follows. Overall in both States of India, more salespeople troubled by the barriers of literacy (overall rank 1) followed by barriers of jargon \& dialects (rank 2), although few are also hindered by barriers of word choice (overall rank 10). In AP, more sales personnel troubled by dialects (rank 1) followed by unclear sound (rank 2) and other barriers. However, 
few of them stumbled by slang (rank 10). In Telangana, more salespeople faced the hurdles because of the barriers of literacy (rank 1) followed by slang (rank 2) and other barriers, while few troubled by-word choice (rank 10).

Table 1: Ranks of language barriers

\begin{tabular}{|c|c|c|c|c|c|c|c|c|c|c|}
\hline Sample & $\begin{array}{l}\text { Semanti } \\
\text { c gaps }\end{array}$ & $\begin{array}{l}\text { Word } \\
\text { choice }\end{array}$ & Pidgins & Slang & Accent & $\begin{array}{l}\text { Unclear } \\
\text { sound }\end{array}$ & $\begin{array}{l}\text { Linguisti } \\
\text { c ability }\end{array}$ & Literacy & Jargon & Dialects \\
\hline Overall & 8 & 10 & 9 & 7 & 5 & 4 & 6 & 1 & 2 & 2 \\
\hline $\mathrm{AP}$ & 7 & 8 & 8 & 10 & 6 & 2 & 5 & 4 & 3 & 1 \\
\hline Telangana & 7 & 10 & 7 & 2 & 3 & 7 & 6 & 1 & 3 & 5 \\
\hline Male total & 7 & 8 & 8 & 10 & 6 & 2 & 5 & 4 & 3 & 1 \\
\hline $\mathrm{AP}$ & 6 & 8 & 9 & 9 & 5 & 2 & 3 & 6 & 1 & 3 \\
\hline Telangana & 6 & 8 & 10 & 2 & 2 & 6 & 8 & 1 & 2 & 5 \\
\hline Female total & 7 & 10 & 7 & 2 & 3 & 7 & 6 & 1 & 3 & 5 \\
\hline $\mathrm{AP}$ & 8 & 8 & 6 & 10 & 6 & 3 & 4 & 2 & 4 & 1 \\
\hline Telangana & 8 & 8 & 3 & 2 & 3 & 8 & 3 & 1 & 3 & 7 \\
\hline Urban total & 3 & 1 & 3 & 3 & 9 & 7 & 3 & 2 & 7 & 10 \\
\hline $\mathrm{AP}$ & 2 & 2 & 5 & 7 & 7 & 2 & 5 & 1 & 7 & 10 \\
\hline Telangana & 6 & 1 & 3 & 2 & 6 & 10 & 3 & 6 & 3 & 6 \\
\hline Rural total & 1 & 9 & 7 & 6 & 7 & 5 & 4 & 3 & 1 & 10 \\
\hline $\mathrm{AP}$ & 1 & 8 & 6 & 8 & 4 & 6 & 2 & 2 & 4 & 10 \\
\hline Telangana & 2 & 8 & 8 & 2 & 10 & 2 & 6 & 2 & 1 & 7 \\
\hline
\end{tabular}

Note: Ranks extracted from the study results appended to this paper.

Among the salesmen in both the States, more are faced the hurdles in dialects (rank 1) followed by unclear sound (rank 2) and other barriers. On the other hand, few deteriorated by slang (rank 10). In AP, more salesmen are foiled by jargon (rank 1) followed by unclear sound (rank 2) and other barriers. Yet, few faced the problems with pidgins and slang (both ranked 9). In Telangana, more salesmen are obstructed in their conversations because of low literacy (rank 1) followed by jargon (rank 2) and other barriers. However, few suffered from pidgins (rank 10). Among the total female sales force, more hindered by low literacy (rank 1) followed by slang (rank 2) and other barriers. Likewise, fewer saleswomen are agonized by word choice (rank 10).

However, in AP, more saleswomen jammed by dialects (ranks 1) followed by literacy (rank 2) and other barriers. Similarly, few of them suffered because of slang (rank 10). As well, the more female selling workforce in Telangana is troubled by low literacy (rank 1) followed by slang (rank 2) and other barriers. Few of them in Telangana is mainly hampered by semantic gaps, word choice, and unclear sound (least ranked, rank 8).

Among sampled sales force in urban markets, more are suffered by word choice (rank 1) followed by literacy (rank 2) and other barriers. Alike, few of them are troubled by dialects (rank 10).

In urban markets of AP, more sales force affected by low literacy (rank 1) followed by unclear sound (rank 2) and other barriers. Correspondingly, fewer salespeople have highly experienced the problems of dialects (rank 10). In Telangana, the sales force in urban markets is impeded by word choice (rank 1) followed by slang (rank 2) and other barriers. However, few salespeople are witnessed by problems of unclear sound (rank 10).

Among the sales staff at rural markets in both the States, more are fenced mainly by the jargon \& dialects (both ranked 1) followed by literacy (rank 3) and other barriers. In the same way, few of them also expressed that they are mainly restricted by dialects (rank 10) in rural markets.

However, in AP, more salespeople in rural markets are highly perceived the semantic gaps (rank 1) followed by barriers of linguistic ability \& literacy (both ranked 2), and jargon (rank 4). Besides, the small number of salespeople told that they struggled with the barrier of dialects (rank 10) in rural markets.

In the rural markets of Telangana, more salespeople obstructed by jargon (rank 1) followed by semantic gaps, slang, unclear sound, and literacy (all are ranked 2). Whereas few of them has faced the difficulties in speaking with the rural customers in Telangana because of dialects (rank 7), word choice \& pidgins (ranked 8), and accent (rank 10).

Altogether, the majority of salespeople in both AP and the Telangana States seems highly pragmatic to the barriers of literacy, jargon, dialects, unclear sound, and accent. However, few are deterrent because 
of word choice, pidgins, semantic gaps, slang, and linguistic ability. In urban markets, more sales force averted by low literacy \& word choice. Whereas in rural markets the condition of salespeople depicted that, they are hostile to jargon \& semantic gaps. Explicitly, the more female sales force is intimidated by literacy, jargon, and dialects. However, more salesmen are apprehensive about dialects, unclear sound, and jargon.

\section{Discussion}

Salespersons use good language that is to be more intelligible to the customers for making a sale. However, the intelligibility of Telugu language would be better in the clear speeches than in the conversational speeches (Durisala, Prakash, Nambi, \& Batra, 2011). A clear speech is the slow-speaking, pausing, and enunciating during the spell of sentences. A conversational speech is the exchange of feelings and thoughts during the speech. Therefore, as the big benefit-talkers in personal selling, salespeople would usually change their acoustic characteristics and they would try to shift from conversational speeches to clear speeches (Ferguson \& Kewley-Port, 2007).

However, among the native Telugu speakers with normal hearing, the speech recognition levels are usually not uniform because of the barriers such as noise, male voice, competing speech, and some other related issues of language barriers (Hygge, Ro"nnberg, Larsby, \& Arlinger, 1992; Tanniru et al., 2017). Normally, the interference of these kinds of barriers in the conversations would often refer to informational masking (Schneider, Li, \& Daneman, 2007).

In this background, this study focused on language barriers that would reduce the clarity in the conversations of the salespeople in personal selling. It is found that the sample of 180 salespeople in AP and Telangana States of India who is using the Telugu language to make a sale has the language barriers of literacy, jargon, dialects, unclear sound, accent, linguistic ability, slang, semantic gaps, pidgins, and word choice. The rationale behind these barriers is as follows.

Majority people in both AP and Telangana speak in Telugu language but with little differences in the vocabulary and grammar (Prabhakar Babu, 1977). Actually, Telangana is part of AP before its bifurcation on 2 June 2014 (indiacode.nic.in, 2014). However, by ancestry, people of both States have the influence of 'mandalika bhashalu' means local regional languages or languages of majority people in the particular areas (Usha Ponnala, 1998). Henceforth, the blend of all such mandalikas is the core Telugu language that the people speak in both the States (Campbell \& Anantam, 1905). Outwardly, key differences are existed within and between the mandalikas of rural and urban areas of both the States. Accordingly, in the conversations of people in both States, same words would convey different meanings and the people would use different words with altered slangs and accents to describe the same objects. As a result, the barriers such as semantic gaps, word choice, pidgins, and dialects would inhibit their conversations.

For instance, of the 13 districts in AP and 31 districts in Telangana, people have many differences in their language because they speak Telugu with completely different word choices, jargons, and dialects. To exemplify, in AP, people would convey the meaning of English word 'more' usually by says 'marinta' and in Telangana people generally says it as 'masthu'.

Further, within the State of AP, people of different districts use different words to convey the meaning of 'more' as they say 'ekkuva', 'marinni', 'inka', 'hechu', 'jasthi', 'mikkili'. Likewise, within the State of Telangana, in different districts, people say 'ginni', 'chala', 'chana', 'boledu' to convey the same is meaning. However, they would pronounce these words in distinct slangs popularly known as Telangana, Rayalaseema, Uttar Andhra, Nellore, Krishna, and the Godavari.

However, these well-known slangs also change between districts that would supplement with some unclear sound in speeches. Let us say, the people of Srikakulam district in AP had different tone accent while comparing to others. They pronounce the English question word 'what' as 'emi' with low-pitched voice, but in Krishna district, people spell it as 'endhi' with an utter male voice. In East and West Godavari districts, they voiced it as 'entanday' with a lot of polite slang that portrays much humor and funniness.

Further, people in Telangana use few Urdu words in their Telugu conversations. In the Adilabad district, people would mix Marathi words because three-fourths of its land neighbored to the State of Maharashtra. Likewise, people in the rural areas of Mahbubnagar, Medak, and Nizamabad districts 
would merge Kannada words with Telugu, as they are adjacent to the State of Karnataka. This would lead to confront the language barriers of literacy, and linguistic ability during the conversations.

Similarly, the people of Srikakulam and Vizianagaram districts in AP have the boundary of Odisha state. Obviously, few people in these two districts would mix some words of Oriya language in their conversations. As well, people of Chittoor district would use Tamil words adapted from their boundary of Tamil Nadu State, and the people of Anantapur district would habituate to mix the Kannada words in their conversations because of neighbor State of Karnataka.

It would imply that this discussion has the rationale behind the barriers in the Telugu language that are troubled the salespeople in personal selling. However, Gopalakrishna, Garrett, Mantrala, and Sridhar (2016) reveal the positive relationship between the dynamic behavior of sales force and sales potential in different districts. To overcome the language barriers, I would advise the salespeople to make many efforts to adapt the typical local regional languages of various districts in AP and Telangana States that not only develop their conversational abilities but also reduce the chances of confronting the language barriers in personal selling.

However, Cross, Brashear, Rigdon, and Bellenger (2007) recognize that there is a positive effect of sales force training programs on their overall performances as well as on the relationship competencies and customer orientation. Therefore, we suggest that the direct selling companies in India have to provide training to their sales teams to develop the communication skills in various indigenous languages that people use in the States like AP and Telangana that has the influence of regional languages.

\subsection{Conclusion}

Being a popular promotional method in marketing campaigns, personal selling encompasses the specialized skills and abilities of the sales force to communicate with customers and convince them to make a sale complete and successful. Therefore, the language of sales force would play a significant role to motivate the customers for buying a product. However, it is felt that the large network of the sales force in the southern States of India has some challenges in personal selling due to the multi-lingual profiles of customers. Hence, a sample of 180 salespeople is interviewed to delineate the language barriers in AP and Telangana States of India.

Findings reveal that more sales personnel are experienced the language barriers of literacy, jargon, dialects, unclear sound, and accent. Few salespeople are troubled by the barriers of word choice, pidgins, semantic gaps, slang, and linguistic ability.

To conclude, both male and female sales force in urban and rural markets of two southern States of India have witnessed the barriers in the Telugu language, and these resulted experiences of the sales force are different in the two States by gender and market locations.

\section{Limitations}

This study used non-probability sampling method for sample selection. Therefore, it is not generalized the language barriers of the sales force in personal selling. It involved only the salespeople who made the conversations with their customers in the Telugu language, but it did not involve the sales force who uses other regional languages such as Urdu, Hindi, English, Tamil, Banjara, Lambadi, and Gondi. As did this, we have reduced the bias to clearly understand the barriers in the Telugu language by interviewed the salespeople in both rural and urban areas of AP and Telangana States in India.

\subsection{Further research}

Various barriers of language would trouble the conversations of the sales force. However, this study focused on oral conversations of salespeople in the Telugu language. Still, there is a scope to conduct further research on verbal and non-verbal barriers to the sales force in personal selling.

Similarly, a follow-on study could extend to other southern States in India such as Tamil Nadu, Odisha, Karnataka, and Maharashtra, to find out the other barriers of Indian regional languages with reference to direct selling activities at rural and urban markets. In fact, this study did not involve the customers in both the States. Hence, parallel studies on the perspectives of customers on language barriers in personal selling would enhance the scope of further research on this subject. 


\section{References}

Agnihotri, R., Gabler, C. B., Itani, O. S., Jaramillo, F., \& Krush, M. T. (2017). Salesperson ambidexterity and customer satisfaction: examining the role of customer demandingness, adaptive selling, and role conflict. Journal of Personal Selling and Sales Management, 37(1), 27-41. https://doi.org/10.1080/08853134.2016.1272053

Agnihotri, R., Vieira, V. A., Senra, K. B., \& Gabler, C. B. (2016). Examining the impact of salesperson interpersonal mentalizing skills on performance: the role of attachment anxiety and subjective happiness. Journal of Personal Selling and Sales Management, 36(2), 174-189. https://doi.org/10.1080/08853134.2016.1178071

Albers, S., Krafft, M., \& Mantrala, M. (2010). Special section on Enhancing Sales Force Productivity. International Journal of Research in Marketing, 27(1), 44-45. https://doi.org/10.1016/j.ijresmar.2009.12.006

Albers, S., Raman, K., \& Lee, N. (2015). Trends in optimization models of sales force management. Journal of Personal Selling and Sales Management, 35(4), 275-291. https://doi.org/10.1080/08853134.2015.1085807

Anderson, S. R. (2012). Languages: a very short introduction.Languages. https://doi.org/10.1093/actrade/9780199590599.001.0001

Annamalai, E. (2008). Contexts of multilingualism. In Language in South Asia (pp. 223-234). https://doi.org/10.1017/CBO9780511619069.013

Basu, A. K., Srinivasan, L. V., \& Staelin, R. (1985). Salesforce Compensation Plan: And Agency Theoretic Perspective. Marketing Science, 4(4), 267-291.

Becton, J. B., Gilstrap, J. B., \& Forsyth, M. (2017). Preventing and correcting workplace harassment: Guidelines for employers. Business Horizons, 60(1), 101-111. https://doi.org/10.1016/j.bushor.2016.09.005

Bhaskararao, P., \& Ray, A. (2017). Telugu. Journal of the International Phonetic Association, 47(02), 231-241. https://doi.org/10.1017/S0025100316000207

Bhattacharya, U. (2017). Colonization and English ideologies in India: a language policy perspective. Language Policy, 16(1). https://doi.org/10.1007/s10993-015-9399-2

Businesstopia.net. (2018). Language Barriers to Communication. Retrieved May 21, 2018, from https://www.businesstopia.net/communication/language-barriers

Caldieraro, F., \& Coughlan, A. T. (2009). Optimal Sales Force Diversification and Group Incentive Payments. Marketing Science, 28(6), 1009-1026. https://doi.org/10.1287/mksc.1090.0493

Campbell \& Anantam (Ed.). (1905). A Progressive Grammer of the Telugu Language (Second). Madras: SPCK Press, Vepery, Madras. Retrieved from

https://ia902706.us.archive.org/28/items/aprogressivegra00ardegoog/aprogressivegra00ardegoog.pdf

Census of India. (2011). Population composition. Census of India, 11-28.

Chaudhary, S. (2008). Foreigners and foreign languages in India: A sociolinguistic history. Foreigners and Foreign Languages in India: A Sociolinguistic History. https:// doi.org/10.1017/UPO9788175968493

Cross, M. E., Brashear, T. G., Rigdon, E. E., \& Bellenger, D. N. (2007). Customer orientation and salesperson performance. European Journal of Marketing, 41(7/8), 821-835. https://doi.org/10.1108/03090560710752410

Currivan, D. B. (2011). Conversational Interviewing. Encyclopedia of Survey Research Methods. https://doi.org/10.4135/9781412963947

DeVincentis, J. R., \& Rackham, N. (2015). Breadth of a salesman. In Pricing and the Sales Force (pp. 136-145). https://doi.org/10.4324/9781315762463

Dragojevic, M., Berglund, C., \& Blauvelt, T. K. (2018). Figuring Out Who's Who: The Role of Social Categorization in the Language Attitudes Process. Journal of Language and Social Psychology, 37(1), 28-50. https://doi.org/10.1177/0261927X17706942

Durisala, N., Prakash, S. G. R., Nambi, A., \& Batra, R. (2011). Intelligibility and Acoustic Characteristics of Clear and Conversational Speech in Telugu (A South Indian Dravidian Language). Indian Journal of Otolaryngology and Head and Neck Surgery, 63(2), 165-171. https://doi.org/10.1007/s12070-011-0241-7

Eira, C. (2008). Linguists and communities: Discursive practice and the status of collaborative language work in indigenous communities. In Language and Intercultural Communication (Vol. 8, pp. 278-297). https://doi.org/10.1080/14708470802303108

El Banna, A., Papadopoulos, N., Murphy, S. A., Rod, M., \& Rojas-Méndez, J. I. (2018). Ethnic identity, consumer ethnocentrism, and purchase intentions among bi-cultural ethnic consumers: "Divided loyalties" or "dual allegiance"? Journal of Business Research, 82, 310-319. https://doi.org/10.1016/j.jbusres.2017.09.010

Euromonitor. (2012). Retailing in India - Jan 2016. Growth (Lakeland), (March), 1-21.

Factors, S., Maintenance, L., \& Shift, L. (2000). Language Maintenance, Shift, and Death. Language, 493-49.

Feng, Y., Guo, Z., \& Chiang, W. K. (2009). Optimal Digital Content Distribution Strategy in the Presence of the Consumer-to-Consumer Channel. Journal of Management Information Systems, 25(4), 241-270.

https://doi.org/10.2753/MIS0742-1222250408 
Ferguson, S. H., \& Kewley-Port, D. (2007). Talker Differences in Clear and Conversational Speech: Acoustic Characteristics of Vowels. Journal of Speech Language and Hearing Research, 50(5), 1241. https:/ / doi.org/10.1044/1092-4388(2007/087)

Fishman, J. A. (1989). Language and ethnicity in minority sociolinguistic perspective. Multilingual Matters.

Gabler, C. B., \& Hill, R. P. (2015). Abusive supervision, distributive justice, and work-life balance: Perspectives from salespeople and managers. Journal of Personal Selling and Sales Management, 35(3), 247-261. https://doi.org/10.1080/08853134.2015.1058167

Geiger, S., \& Turley, D. (2006). The Perceived Impact of Information Technology on Salespeople's Relational Competencies. Journal of Marketing Management, 22(7-8), 827-851. https:// doi.org/10.1362/026725706778612158

Glaz, A. (2001). Language Diversity and Cognitive Representations (review). Language. https:// doi.org/10.1353/lan.2001.0084

Gopalakrishna, S., Garrett, J., Mantrala, M. K., \& Sridhar, S. (2016). Assessing sales contest effectiveness: the role of salesperson and sales district characteristics. Marketing Letters, 27(3), 589-602. https://doi.org/10.1007/s11002014-9341-y

Granfield, M., \& Nicols, A. (1975). Economic and Marketing Aspects of the Direct Selling Industry. Journal of Retailing, 51(1), 33-49. https://doi.org/00224359

Gregory, C. A., \& Bhatia, T. K. (2002). Advertising in Rural India: Language, Marketing Communication, and Consumerism. The Journal of Asian Studies, 61(1), 286. https:/ / doi.org/10.2307/2700258

Groff, C. (2017). Language and language-in-education planning in multilingual India: a minoritized language perspective. Language Policy, 16(2), 135-164. https:/ / doi.org/10.1007/s10993-015-9397-4

Hammann, P. (2005). Personal selling. European Journal of Marketing, 13(6), 141-176.

Hansen, J. D., Lund, D. J., \& DeCarlo, T. E. (2016). A process model of buyer responses to salesperson transgressions and recovery efforts: The impact of salesperson orientation. Journal of Personal Selling and Sales Management, 36(1), 59-73. https://doi.org/10.1080/08853134.2016.1149352

Harrison, D. E., \& Hair, J. F. (2017). The Use of Technology in Direct-Selling Marketing Channels: Digital Avenues for Dynamic Growth. Journal of Marketing Channels, 24(1-2), 39-50. https://doi.org/10.1080/1046669X.2017.1346979

Homburg, C., Müller, M., \& Klarmann, M. (2011). When does salespeople's customer orientation lead to customer loyalty? The differential effects of relational and functional customer orientation. Journal of the Academy of Marketing Science, 39(6), 795-812. https://doi.org/10.1007/s11747-010-0220-7

hul.co.in. (2018). Project Shakti | Sustainable Living | Hindustan Unilever Limited website. Retrieved May 16, 2018, from https://www.hul.co.in/sustainable-living/case-studies/enhancing-livelihoods-through-projectshakti.html

Hygge, S., Ro“nnberg, J., Larsby, B., \& Arlinger, S. (1992). Normal-Hearing and Hearing- Impaired Subjects' Ability to Just Follow Conversation in Competing Speech, Reversed Speech, and Noise Backgrounds. Journal of Speech Language and Hearing Research, 35(1), 208. https:/ / doi.org/10.1044/jshr.3501.208

indiacode.nic.in. (2014). THE ANDHRA PRADESH REORGANISATION ACT, 2014. Retrieved May 21, 2018, from https://indiacode.nic.in/bitstream/123456789/2123/1/201406.pdf\#search=acts 2014

Jones, E., Brown, S. P., Zoltners, A. A., \& Weitz, B. A. (2005). The changing environment of selling and sales management? Journal of Personal Selling and Sales Management, 25(2), 105 . https:// doi.org/10.1080/08853134.2005.10749052

KPMG. (2017). Direct 2016: The contribution of Direct Selling to building India. Retrieved from https://assets.kpmg.com/content/dam/kpmg/in/pdf/2016/12/Direct-2016.pdf

Kräkel, M., \& Schöttner, A. (2016). Optimal sales force compensation. Journal of Economic Behavior and Organization, 126, 179-195. https://doi.org/10.1016/j.jebo.2016.03.015

Krishnamoorthy, A., Misra, S., \& Prasad, A. (2005). Scheduling sales force training: Theory and evidence. International Journal of Research in Marketing, 22(4), 427-440. https:/ / doi.org/10.1016/j.ijresmar.2005.09.001

LaDousa, C. (2010). On mother and other tongues: Sociolinguistics, schools, and language ideology in northern India. Language Sciences, 32(6), 602-614. https:/ / doi.org/10.1016/j.langsci.2010.08.001

Laitin, D. D. (1993). Migration and language shift in urban India. International Journal of the Sociology of Language, 103(1), 57-72. https:// doi.org/10.1515/ijsl.1993.103.57

Larsen, V. (1993). A Sociolinguistic Approach to Gender and Personal Selling. ACR North American Advances, NA-20. Retrieved from http://acrwebsite.org/volumes/9835/volumes/v20/NA-20

Lavrakas, P. J., \& Battaglia, M. (2008). Encyclopedia of Survey Research Methods. In Encyclopedia of Survey Research Methods (p. 429). https://doi.org/http://dx.doi.org.zorac.aub.aau.dk/10.4135/9781412963947.n322

MacKenzie, P. J. (2009). Mother tongue first multilingual education among the tribal communities in India. International Journal of Bilingual Education and Bilingualism, 12(4), 369-385. 
https://doi.org/10.1080/13670050902935797

Mackey, W. F. (1966). The measurement of bilingual behavior. Canadian Psychologist/Psychologie Canadienne, 7a(2), 7592. https://doi.org/10.1037/h0083093

Madalli, D. P., \& Patel, D. (2009). Issues in Indian languages computing in particular reference to search and retrieval in Telugu language. Library Hi Tech, 27(3), 450-459. https://doi.org/10.1108/07378830910988568

Madan Shankar, K., Kannan, D., \& Udhaya Kumar, P. (2017). Analyzing sustainable manufacturing practices - A case study in Indian context. Journal of Cleaner Production, 164, 1332-1343. https://doi.org/10.1016/j.jclepro.2017.05.097

Madhani, P. M. (2013). Managing Sales Compensation. Compensation E Benefits Review, 45(2), $105-114$. https://doi.org/10.1177/0886368713490639

mapsofindia.com. (2013). Languages in Andhra Pradesh. Retrieved May 21, 2018, from https://www.mapsofindia.com/andhra-pradesh/languages.html

Mariadoss, B. J., Milewicz, C., Lee, S., \& Sahaym, A. (2014). Salesperson competitive intelligence and performance: The role of product knowledge and sales force automation usage. Industrial Marketing Management, 43(1), 136145. https://doi.org/10.1016/j.indmarman.2013.08.005

Murphy, A. (2012). Other tongues: rethinking the language debates in India. Journal of Multilingual and Multicultural Development. https://doi.org/10.1080/01434632.2011.614076

Plough, I. C. (2014). Development of a test of speaking proficiency in multiple languages. Papers in Language Testing and Assessment, 3(2), 27-52.

Prabhakar Babu, B. A. (1977). Emphasis in Telugu. Phonetica, 34, 191-199. Retrieved from https:/ / www.scopus.com/inward/record.url?eid=2-s2.00017669215\&partnerID $=40 \& m d 5=9464417732$ ea529615b952668fe69baa

Proctor, L. M. (2014). English and Globalization in India: The Fractal Nature of Discourse. Journal of Linguistic Anthropology, 24(3), 294-314. https://doi.org/10.1111/jola.12056

Quach, S., \& Thaichon, P. (2018). Dark motives-counterfeit selling framework. Marketing Intelligence E Planning, MIP04-2017-0069. https:// doi.org/10.1108/MIP-04-2017-0069

Reid, D. A., Plank, R. E., Peterson, R. M., \& Rich, G. A. (2017). Examining the use of sales force management practices. Journal of Business E Industrial Marketing, 32(7), 974-986. https:/ / doi.org/10.1108/JBIM-02-2016-0040

Román, S., \& Rodríguez, R. (2015). The influence of sales force technology use on outcome performance. Journal of Business E Industrial Marketing, 30(6), 771-783. https:/ / doi.org/10.1108/JBIM-01-2015-0001

Salzmann, Z. (2003). An Introduction to Sociolinguistics (review). Language, 79(4), 824-825. https:/ / doi.org/10.1353/lan.2003.0268

Sandhu, P. (2015). Stylizing voices, stances, and identities related to medium of education in India. Multilingua, 34(2), 211-235. https://doi.org/10.1515/multi-2014-1012

Schneider, B. A., Li, L., \& Daneman, M. (2007). How Competing Speech Interferes with Speech Comprehension in Everyday Listening Situations. Journal of the American Academy of Audiology, 18(7), 559-572. https://doi.org/10.3766/jaaa.18.7.4

Shannahan, R. J., Bush, A. J., Shannahan, K. L. J., \& Moncrief, W. C. (2017). How salesperson perceptions of customers' pro-social behaviors help drive salesperson performance. Industrial Marketing Management, 62, 36-50. https://doi.org/10.1016/j.indmarman.2015.05.004

Sharma, A. (2016). What personal selling and sales management recommendations from developed markets are relevant in emerging markets? Journal of Personal Selling and Sales Management, 36(2), 89-104 . https://doi.org/10.1080/08853134.2016.1185951

Shree, D., Gupta, A., \& Sagar, M. (2017). Effectiveness of cause-related marketing for differential positioning of market entrant in developing market: An exploratory study in Indian context. International Journal of Nonprofit and Voluntary Sector Marketing, 22(2). https:/ / doi.org/10.1002/nvsm.1573

Shukla, S. (2006). Hindi. In Encyclopedia of Language E Linguistics (pp. 303-305). https://doi.org/10.1016/B0-08044854-2/02219-7

Siguaw, J. A., Kimes, S. E., \& Gassenheimer, J. B. (2003). B2B sales force productivity: Applications of revenue management strategies to sales management. Industrial Marketing Management, 32(7), 539-551. https:// doi.org/10.1016/S0019-8501(02)00278-X

Singh, D., Pattnaik, C., Gaur, A. S., \& Ketencioglu, E. (2018). Corporate expansion during pro-market reforms in emerging markets: The contingent value of group affiliation and diversification. Journal of Business Research, 82, 220-229. https://doi.org/10.1016/j.jbusres.2017.09.043

Singh, J. K., Misra, G., \& De Raad, B. (2013). Personality Structure in the Trait Lexicon of Hindi, a Major Language Spoken in India. European Journal of Personality, 27(6), 605-620. https://doi.org/10.1002/ per.1940 
Singh, R., Kumar, N., \& Puri, S. (2017). Thought self-leadership strategies and sales performance: integrating selling skills and adaptive selling behavior as missing links. Journal of Business E Industrial Marketing, 32(5), $652-663$. https://doi.org/10.1108/JBIM-06-2016-0127

Smith, B., Andras, T. L., \& Rosenbloom, B. (2012). Transformational Leadership: Managing the Twenty-First Century Sales Force. Psychology and Marketing, 29(6), 434-444. https:/ / doi.org/10.1002/mar.20532

Solomonson, F. (1922). The genesis of language. Quarterly Journal of Speech, 8(4), 372-379. https:/ / doi.org/10.1080/00335632209379401

spoj.com. (2018). Standard Competition Ranking. Retrieved from http://www.spoj.com/CEG5/problems/EASYRANK.pdf

Sravanthi, M. C., Prathyusha, K., \& Mamidi, R. (2015). A dialogue system for telugu, a resource-poor language. In Lecture Notes in Computer Science (including subseries Lecture Notes in Artificial Intelligence and Lecture Notes in Bioinformatics) (Vol. 9042, pp. 364-374). https://doi.org/10.1007/978-3-319-18117-2_27

Sreekumar, P. (2009). Francis Whyte Ellis and the Beginning of Comparative Dravidian Linguistics. Historiographia Linguistica, 36(1), 75-95. https://doi.org/10.1075/hl.36.1.04sre

Sunardi, O., Widyarini, M., \& Tjakraatmadja, J. H. (2012). The Impact of Sales Forces Training Program to Employees Behaviour Styles (A Quasi-experimental Case Study In a Medium Sized Enterprise). Procedia Economics and Finance, 4, 264-273. https:/ / doi.org/10.1016/S2212-5671(12)00341-3

Swani, K., Brown, B. P., \& Milne, G. R. (2014). Should tweets differ for B2B and B2C? An analysis of Fortune 500 companies' Twitter communications. Industrial Marketing Management, 43(5), 873-881. https:// doi.org/10.1016/j.indmarman.2014.04.012

Tanniru, K., Narne, V. K., Jain, C., Konadath, S., Singh, N. K., Sreenivas, K. J. R., \& Anusha, K. (2017). Development of equally intelligible Telugu sentence-lists to test speech recognition in noise. International Journal of Audiology, 56(9), 664-671. https://doi.org/10.1080/14992027.2017.1307530

Thaler, R. H., \& Tucker, W. (2013). Smarter information, smarter consumers. Harvard Business Review.

The Tribune. (2012). Model norms to curb Ponzi schemes. Retrieved May 16, 2018, from http://www.tribuneindia.com/news/business/model-norms-to-curb-ponzi-schemes/294282.html

Trautmann, T. R. (2004). Discovering Aryan and Dravidian in British India: a tale of two cities. Historiographia Linguistica, 31(1), 33-58. https://doi.org/10.1075/hl.31.1.04tra

Trivedi, M., Gauri, D. K., \& Ma, Y. (2017). Measuring the Efficiency of Category-Level Sales Response to Promotions. Management Science, 63(10), 3473-3488. https://doi.org/10.1287/mnsc.2016.2496

Upadhyay, R. K., \& Hasnain, S. I. (2017). Linguistic diversity and biodiversity. Lingua, 195, 110-123 . https://doi.org/10.1016/j.lingua.2017.06.002

Usha Ponnala. (1998). Telugu Maandalikalu. Hyderabad: Telugu Akademi. Retrieved from https://ia601602.us.archive.org/25/items/in.ernet.dli.2015.162200/2015.162200.Telugu-Mandalikalu.pdf

Verma, Y. S. (1980). Marketing in Rural India. Management International Review, $20(4), 47$.

Weitz, B. A., \& Bradford, K. D. (1999). Personal Selling and Sales Management: A Relationship Marketing Perspective. Journal of the Academy of Marketing Science, 27(2), 241-254. https:/ / doi.org/10.1177/0092070399272008

Appendix: Study results.

\begin{tabular}{|c|c|c|c|c|c|c|c|c|c|c|}
\hline \multirow[b]{2}{*}{ Sample } & \multicolumn{10}{|c|}{ Language barriers and number of respondents. } \\
\hline & $\begin{array}{l}\text { Semantic } \\
\text { gaps }\end{array}$ & $\begin{array}{l}\text { Word } \\
\text { choice }\end{array}$ & Pidgins & Slang & Accent & $\begin{array}{l}\text { Unclear } \\
\text { sound }\end{array}$ & $\begin{array}{l}\text { Linguistic } \\
\text { ability }\end{array}$ & Literacy & Jargon & Dialects \\
\hline Overall & $13(8)$ & 10(10) & $11(9)$ & $16(7)$ & $19(5)$ & $20(4)$ & $18(6)$ & $27(1)$ & $23(2)$ & $23(2)$ \\
\hline $\mathrm{AP}$ & $7(7)$ & $5(8)$ & $5(8)$ & $3(10)$ & $9(6)$ & $14(2)$ & $11(5)$ & $12(4)$ & $13(3)$ & $15(1)$ \\
\hline Telangana & $6(7)$ & $5(10)$ & $6(7)$ & $13(2)$ & $10(3)$ & $6(7)$ & $7(6)$ & $15(1)$ & $10(3)$ & $8(5)$ \\
\hline Male total & $7(7)$ & $5(8)$ & $5(8)$ & $3(10)$ & $9(6)$ & $14(2)$ & $11(5)$ & $12(4)$ & $13(3)$ & $15(1)$ \\
\hline $\mathrm{AP}$ & $5(6)$ & $3(8)$ & $2(9)$ & $2(9)$ & $6(5)$ & $8(2)$ & $7(3)$ & $5(6)$ & $9(1)$ & $7(3)$ \\
\hline Telangana & $4(6)$ & $3(8)$ & $2(10)$ & $6(2)$ & $6(2)$ & $4(6)$ & $3(8)$ & $7(1)$ & $6(2)$ & $5(5)$ \\
\hline Female total & $6(7)$ & $5(10)$ & $6(7)$ & $13(2)$ & $10(3)$ & $6(7)$ & $7(6)$ & $15(1)$ & $10(3)$ & $8(5)$ \\
\hline $\mathrm{AP}$ & $2(8)$ & $2(8)$ & $3(6)$ & $1(10)$ & $3(6)$ & $6(3)$ & $4(4)$ & $7(2)$ & $4(4)$ & $8(1)$ \\
\hline Telangana & $2(8)$ & $2(8)$ & $4(3)$ & $7(2)$ & $4(3)$ & $2(8)$ & $4(3)$ & $8(1)$ & $4(3)$ & $3(7)$ \\
\hline Urban total & $9(3)$ & $12(1)$ & $9(3)$ & $9(3)$ & $7(9)$ & $8(7)$ & $9(3)$ & $11(2)$ & $8(7)$ & $5(10)$ \\
\hline $\mathrm{AP}$ & $3(6)$ & $6(1)$ & $4(3)$ & $5(2)$ & $3(6)$ & $2(10)$ & $4(3)$ & $3(6)$ & $4(3)$ & $3(6)$ \\
\hline Telangana & $6(2)$ & $6(2)$ & $5(5)$ & $4(7)$ & $4(7)$ & $6(2)$ & $5(5)$ & $8(1)$ & $4(7)$ & $2(10)$ \\
\hline Rural total & $13(1)$ & $6(9)$ & $7(7)$ & $9(6)$ & $7(7)$ & $10(5)$ & $11(4)$ & $12(3)$ & $13(1)$ & $5(10)$ \\
\hline $\mathrm{AP}$ & $6(2)$ & $3(8)$ & $3(8)$ & $6(2)$ & $2(10)$ & $6(2)$ & $5(6)$ & $6(2)$ & $8(1)$ & $4(7)$ \\
\hline Telangana & $7(1)$ & $3(8)$ & $4(6)$ & $3(8)$ & $5(4)$ & $4(6)$ & $6(2)$ & $6(2)$ & $5(4)$ & $1(10)$ \\
\hline
\end{tabular}

Note: 1 . Figures in brackets indicate ranks of language barriers in each row.

2. Ranks allotted in ascending order by the number of respondents highly perceived the barrier. 